\title{
Pendekatan Cognitive Behavior Therapy (CBT) Teknik Bibliotherapy Sebagai Intervensi dalam Konseling Kelompok
}

\author{
Insan Suwanto \\ Bimbingan dan Konseling, STKIP Singkawang, Indonesia \\ Correspondence: email.insansuwanto@gmail.com
}

\begin{abstract}
Abstrack: Konseling kelompok dapat dijadikan sebagai sarana untuk membantu individu dalam mencapai perkembangan dan bantuan untuk mengatasi persoalan psikologis. Cognitive behavior therapy sebagai pendekatan dalam pelaksanaan layanan konseling kelompok dapat pula dijadikan sebagai sarana modifikasi perilaku individu untuk menentang pikiran (dan emosi) yang salah. Bibliotherapy sebagai sebuah teknik dalam kegiatan layanan konseling kelompok menjadi salah satu alternatif kebutuhan menangani permasalahan perkembangan individual dalam kehidupan bermasyarakat. Bibliotherapy mencakup tiga tahapan yang berfokus pada identifikasi, katarsis, dan wawasan. Individu mengidentifikasi bacaan yang disesuaikan dengan karakter, berkaitan dengan masalah yang dihadapi, dan pengalaman yang menuju pada pelepasan katarsis. Metode dalam artikel ini menggunakan studi literatur dan kajian penelitian terkait. Artikel ini dapat dijadikan sebagai referensi peneliti selanjutnya untuk membangun kerangka kerja teoritis dan metodologi.
\end{abstract}

Kata kunci: CBT, Bibliotherapy, Konseling Kelompok

\begin{abstract}
Group counseling can be used as a means to assist individuals in achieving development and assistance to overcome psychological problems. Cognitive behavior therapy as an approach in the implementation of group counseling services can also be used as a means of modifying individual behavior to challenge wrong thoughts (also emotions). Bibliotherapy as a technique in group counseling service activities is an alternative need to address the problems of individual development in social life. Bibliotherapy includes three stages that focus on identification, catharsis, and insight. Individuals identify readings that are adapted to the character, related to the problem at hand, and experiences that lead to the release of catharsis. The method in this article uses literature studies and related research studies. This article can be used as a reference for further researchers to build a theoretical framework and methodology.
\end{abstract}

Keyword: CBT, Bibliotherapy, Group Counseling

Ini adalah artikel dengan akses terbuka dibawah licenci $C C B Y-N C-4.0$ (c) () () (https://creativecommons.org/licenses/by-nc/4.0/)

\section{PENDAHULUAN}

Konseling kelompok dapat dijadikan sebagai sarana untuk membantu individu dalam mencapai perkembangan, serta menjadi salah satu bantuan untuk mengatasi persoalan psikologis. Konseling kelompok bertujuan membantu mempercepat dan memperlancar penyelesaian masalah yang dihadapi siswa
(Wibowo, 2005; 305). Konseling kelompok adalah suatu bantuan kepada individu dalam situasi kelompok yang bersifat pencegahan dan penyembuhan, serta diarahkan pada pemberian kemudahan dalam perkembangan dan pertumbuhannya (Kurnanto, 2013:7-8).

Cognitive Behavior Therapy (CBT) adalah salah satu pendekatan yang paling populer di setting konseling kelompok. 
Pendekatan ini juga dapat digunakan untuk memenuhi persyaratan pencapaian tujuan dalam konseling kelompok (Corey, 2013; 302). CBT cocok untuk terapi kelompok karena anggotanya diajarkan untuk menerapkan asas-asasnya satu sama lain dalam kelompok. Ellis (Corey, 2013) merekomendasikan agar saat menggunakan format (konseling) kelompok berfokus pada teknik spesifik untuk mengubah pikiran mengalahkan diri klien dalam berbagai situasi konkret. Selain memodifikasi keyakinan, pendekatan ini membantu anggota kelompok melihat bagaimana kepercayaan mereka memengaruhi apa yang mereka rasakan dan apa yang mereka lakukan. Oleh karena itu, salah satu yang dapat menjadi teknik dalam konseling kelompok pendekatan CBT adalah teknik Bibliotherapy.

Bibliotherapy adalah penggunaan literatur untuk membantu individu dalam menangani masalah kesehatan mental serta masalah transisi kehidupan (White \& Nancy, 2011: 12). Bibliotherapy ini mencakup tugas membaca terhadap bahan bacaan yang terseleksi, terencana, dan terarah sebagai suatu prosedur treatment atau tindakan dengan tujuan penyembuhan karena diyakini bahwa pembaca dapat mempengaruhi sikap, perasaan, dan perilaku individu sesuai dengan yang diharapkan. Menurut Shrodes (White \& Nancy, 2011: 12).

Bibliotherapy mencakup tiga tahapan yang berfokus pada identifikasi, katarsis, dan wawasan. Individu mengidentifikasi bacaan yang disesuaikan dengan karakter, berkaitan dengan masalah yang dihadapi, dan pengalaman yang menuju pada pelepasan katarsis (wawasan, pertumbuhan pribadi, dan pengembangan).

Bibliotherapy dapat digunakan dalam konteks individu atau kelompok. Dalam konteks kelompok, intervensi ini membantu dalam mengembangkan aliansi bekerja konselor dan klien, kepercayaan, kohesi kelompok, eksplorasi diri, wawasan, dan pertumbuhan (White \& Nancy, 2011: 18). Banyak informasi yang dapat diperoleh melalui kegiatan membaca bersama dan membaca buku yang ditugaskan. Membaca bukan hanya sekedar untuk mendapatkan informasi pelajaran dan sember kecerdasan, tetapi dengan membaca dapat dijadikan sebagi sumber dalam pengentasan masalah, buku-buku tersebut dapat dijadikan pedoman untuk mencari solusi dalam pemecahkan masalah.

Berdasarkan pendekatan CBT bahwa mempersepsikan proses bibliotherapy sebagai mekanisme utama dari proses belajar, dan bahan bacaan yang mendidik dapat sebagai bentuk bantuan mengatasi masalah individu (Shechtman, 2009; 23). Asumsi dasar CBT adalah bahwa cara yang penting untuk menghasilkan perubahan yang berlangsung dalam emosi disfungsional dan perilaku untuk mengubah kesalahan dan disfungsional berpikir. Sehingga melalui bibliotherapy individu dapat belajar untuk perubahan pola pikir negatif menjadi sehat yang, menghasilkan perilaku konstruktif positif.

Selanjutnya, bibliotherapy sebagai sebuah teknik dalam kegiatan layanan konseling kelompok menjadi salah satu alternatif kebutuhan menangani permasalahan perkembangan individual dalam kehidupan bermasyarakat mereka. Bibliotherapy sering disebut juga terapi membaca, yang didalam prosesnya seseorang yang mengalami masalah diminta membaca buku-buku yang bersifat membantu dirinya dan memotivasi agar mempercepat penyembuhan. Membaca mengenai kesulitan orang lain yang sama dengan mereka, dapat memberikan kesadaran dan pemahaman terhadap masalah yang dihadapinya (Solikin, 2015).

Hasil penelitian Riyahinia, dkk. (2015) menunjukkan bahwa biblioterapy berkelompok memiliki dampak yang signifikan terhadap self esteem anak-anak. Selanjutnya, penelitian Shechtman \& Rivka (2015) menunjukkan bahwa biblioterapy afektif dapat menjadi metode yang efektif dalam terapi kelompok.

Penggunaan teknik bibliotherapy sebagai salah satu teknik dalam konseling kelompok pendekatan CBT guna menangani permasalahan pada individu perlu dipertimbangkan. Hal ini disebabkan karena teknik bibliotherapy dapat merangsang individu untuk berfikir, mudah, murah, dan dapat dilakukan kapan saja serta melibatkan kemandirian dan partisipasi remaja sendiri secara penuh sehingga efektivitas hasilnya cukup baik.

Oleh karena itu, dengan mengintegrasikan bibliotherapy ke dalam proses konseling kelompok pendekatan CBT, konseli atau siswa akan mendapatkan kesempatan untuk berinteraksi secara dinamis, yang menekankan respon emosional yang diberikan melalui bahanbahan tertulis dan bertujuan untuk membantu individu mengenali, dan mengevaluasi masalah yang ada khususnya masalah individu. 


\section{METODE}

Jenis Penelitian ini merupakan studi literatur dan kepustakaan dengan analisis kualitatif. Yaitu penelitian yang dilakukan dengan menelaah dari berbagai sumber referensi yang relevan, kemudian mensandikingkan dengan berbagai referensi teori dan hasil penelitian serta memberikan hasil temuan pemikiran yang dapat dijadikan sebagai rujukan dalam meneliti selanjutnya

\section{HASIL DAN PEMBAHASAN}

Istilah bibliotherapy berasal dari bahasa Yunani, yaitu biblus berarti buku, dan therapy yaitu upaya bantuan psikologis, oleh karena itu bibliotherapy dapat didefinisikan sebagai penggunaan buku-buku untuk membantu memecahkan masalah. Bibliotherapy merupakan sebuah terapi ekspresif yang didalamnya terdapat hubungan individu dengan isi atau intisari buku, puisi dan tulisan lain sebagai sebuah terapi (Eliasa, 2012).

Menurut pandangan cognitive behavior, bibliotherapy sebagai mempersepsikan kegiatan membaca sebagai mekanisme utama perubahan proses belajar. Dalam pendekatan CBT, dapat dilakukan dalam tertentu dalam format bibliotherapy (Corey, 2013; 298). Keuntungan dari biblioteraphy, seperti efektivitas biaya, ketersediaan yang meluas, dan potensi menjangkau spektrum populasi yang luas. Pendekatan bibliotherapy memiliki dukungan empiris untuk pengobatan depresi, karena berbagai gangguan kecemasan, dan untuk berbagai masalah klinis (Jacobs dalam Corey, 2013; 298).

Menurut Pardeck (dalam Chairani, 2015) Bibliotherapy adalah penatalaksanaan kesehatan mental dengan menggunakan buku untuk membantu meningkatkan coping terhadap perubahan, masalah emosional dan mental.

Bibliotherapy adalah teknik yang memanfaatkan pembacaan buku literatur (Sclabassi, 2012). Keyakinan dalam membaca dapat mempengaruhi sikap individu, perasaan, dan perilaku adalah setua membaca itu sendiri. Bibliotherapy melibatkan pembacaan buku yang dipilih, direncanakan dan dilakukan sebagai prosedur pelaksanaannya dengan tujuan terapeutik (Sclabassi, 2012: 5).

$$
\text { Dalam layanan konseling }
$$

bibliotherapy menawarkan konselor strategi kreatif dan pengalaman. Konselor dapat menggunakan bibliotherapy sebagai intervensi untuk memfasilitasi klien dalam memperoleh keakraban, mengidentifikasi keunikan pribadi, dan perasaan klien (White \& Nancy, 2011). Bibliotherapy juga dapat digunakan sebagai mekanisme terapi untuk membantu membangun hubungan konseling, mengeksplorasi isu-isu gaya hidup dan karir, untuk mempromosikan wawasan dan kesadaran, dan reorientasi dan mengajar kembali (Jackson dalam White \& Nancy, 2011: 12).

Berdasarkan penjelasan di atas, dapat disimpulkan bahwa Bibliotherapy adalah dimana seseorang yang mengalami masalah diminta membaca buku-buku yang bersifat membantu dirinya dan memotivasi agar mempercepat penyembuhan. Membaca mengenai kesulitan orang lain yang sama dengan mereka, dapat memberikan kesadaran dan pemahaman terhadap masalah yang dihadapinya.

Lewat membaca seseorang bisa mengenali dirinya. Informasi dan pengetahuan yang diperoleh dari kegiatan membaca menjadi masukan untuk memecahkan masalah yang dihadapi seseorang. Saat membaca, pembaca menginterpretasi jalan pikiran penulis, menerjemahkan simbol dan huruf kedalam kata dan kalimat yang memiliki makna tertentu, seperti rasa haru dan simpati. Perasaan ini dapat "membersihkan diri" dan mendorong sesorang untuk berperilaku lebih positif.

Menurut Novitawati (2011) intervensi biblioterapi dapat dikelompokkan dalam empat tingkatan, yaitu intelektual, sosial, perilaku, dan emosional. Pada tingkat intelektual individu memperoleh pengetahuan tentang perilaku yang dapat memecahkan masalah, membantu pengertian diri, serta mendapatkan wawasan intelektual. Selanjutnya, individu dapat menyadari ada banyak pilihan dalam menangai masalah.

Pada tingkat sosial, individu dapat mengasah kepekaan sosialnya. Ia dapat melampaui bingkai referensinya sendiri melalui imajinasi orang lain. Teknik ini dapat menguatkan pola-pola sosial, budaya, menyerap nilai kemanusiaan dan saling memiliki.

Pada tingkat perilaku individu akan mendapatkan kepercayaan diri untuk membicarakan masalah-masalah yang sulit didiskusikan akibat perasaan takut, malu, dan bersalah. Lewat membaca, individu didorong untuk diskusi tanpa rasa malu akibat rahasia pribadinya terbongkar. 
Pada tingkat emosional, individu dapat terbawa perasaannya dan mengembangkan kesadaran menyangkut wawasan emosional. Teknik ini dapat menyediakan solusi-solusi terbaik dari rujukan masalah sejenis yang telah dialami orang lain sehingga merangsang kemauan yang kuat pada individu untuk memecahkan masalahnya.

Dalam keterkaitan dengan masalah perilaku pada individu, konseling kelompok CBT teknik Bibliotherapy adalah bantuan berkelompok yang menggunakan literatur seperti buku atau karya sastra untuk membantu anggota kelompok mengatasi masalah yang dialaminya. Dengan memanfaatkan dinamika kelompok dalam konseling kelompok, diharapkan membaca dapat membantu individu memahami diri dan lingkungan, belajar dari orang lain, dan mungkin menemukan solusi untuk masalah mereka.

Bibliotherapy diimplementasikan dalam konseling kelompok sehingga pembaca (anggota kelompok) menjadi pribadi yang terlibat dengan situasi dan karakter dalam buku, dan masalah yang ditangani. Langkah-langkah yang dapat ditempuh dalam konseling kelompok CBT teknik bibliotherapy adalah:

a. Tahap Pembentukan, yaitu tahap untuk membentuk sejumlah individu menjadi satu kelompok yang siap mengembangkan dinamika kelompok untuk mencapai untuk mencapai tujuan bersama. Lebih khusus yang dilakukan dalam tahap ini diantaranya :
1) Identifikasi
kebutuhan
anggota

kelompok.

2) Mentukan waktu yang diperlukan.

3) Merumuskan tujuan utama kelompok.

b. Tahap Peralihan, yaitu tahap untuk mengalihkan kegiatan awal kelompok ke kegiatan berikutnya yang lebih terarah pada pencapaian tujuan kelompok.

c. Tahap Kegiatan, yaitu tahap "kegiatan inti" untuk membahas dan mengentaskan masalah pribadi anggota kelompok. Yang dilakukan dalam tahap ini diantaranya :

1) Awali kegiatan dengan memberikan motivasi dan membuat rasa nyaman dalam kelompok.

2) Setelah merasa nyaman, diskusikan tema buku secara umum.

3) Menentukan bahan yang tepat dengan kebutuhan.

4) Membahas maksud utama dalam buku, bagaimana anggota memecahkan masalah, dan solusi lain yang mungkin untuk masalah yang dialaminya.

d. Tahap Penutupan, yaitu tahapan akhir kegiatan untuk melihat kembali apa yang sudah dilakukan dan dicapai oleh kelompok. Pada akhir pertemuan masing-masing peserta akan menyebutkan secara singkat bagaimana perasaan tentang proses kelompok serta merencanakan kegiatan selanjutnya.

Dengan teknik bibliotherapy, individu yang membaca buku dapat memahami apa yang harus dilakukan sebab pengaruh dari oleh bacaan dan literatur yang memberi banyak informasi dan dapat memotivasi. Selain itu, membaca dapat merubah perasaan, memberikan pemahaman baru dan meningkatkan kemungkinan bahwa individu akan melaksanakan perilaku baru dan diinginkan.

\section{SIMPULAN DAN SARAN}

Dari penjelasan di atas, maka dapat disimpulkan bahwa konseling kelompok CBT teknik bibliotherapy dapat menjadi salah satu alternatif dalam upaya mengatasi masalah individu. Tujuan utama konseling kelompok CBT teknik bibliotherapy ini adalah untuk memberikan informasi guna mengembangkan rasa yang lebih positif dari diri mereka sendiri, belajar tentang dunia, mengatasi stres, memberikan wawasan terhadap suatu masalah, menegaskan pikiran dan perasaan, merangsang diskusi tentang masalah, menciptakan kesadaran orang lain yang memiliki masalah yang sama, memberikan solusi untuk masalah, mengkomunikasikan nilai-nilai dan sikap baru, dan menemukan makna dalam kehidupan yang terkait dengan perilaku yang merugikan.

\section{DAFTAR RUJUKAN}

Chairani, Nabila. 2015. "Potensi Bibliotherapy dalam Mengurangi Kecemasan Akibat Hospitalisasi Pada Anak Usia Sekolah". Jurnal BIMIKI, 3 (1) ISSN 2338-4700.

Corey, Gerald. 2013. Theory and Practice of Counseling and Psychotherapy (9th edition). California: Brooks/Cole.

Eliasa. 2007. "Bibliotherapy Bertema Karir Untuk Meningkatkan Motivasi Karir Pada Mahasiswa Program Studi Bimbingan dan Konseling”. Jurnal Universitas Negeri 
Yogyakarta, hlm 1-14.

Kurnanto, Edi. 2013. Konseling Kelompok. Bandung: ALFABETA.

Novitawati. 2011. "Pengaruh Rational Bibliotherapy terhadap penurunan perilaku Merokok dengan Transtheoritical Model of Behaviour Change sebagai Acuan Pengukuran". Jurnal Anima, 16 (3).

Riyahinia, Makarem, Farajipoor, Haseli. 2015. "The Impact of Group Bibliotherapy on the Self-Esteem of Children Abused by Work Labor". Journal of research Iranian counseling association, Volume 14, Number 54 (7-2015) 2015, 14(54): 111126.

Sclabassi, Sharon Henderson. 2012. Bibliotherapy. Psychotherapy Guidebook : International Psychotherapy Institute.
Shechtman, Zipora \& Rivka Nir-Shfrir. 2008. "The Effect of Affective Bibliotherapy on Clients' Functioning in Group Therapy". International Journal of Group Psychotherapy, 58 (1).

Solikin, Asep. 2015. "Bibliotherapy Sebagai Sebuah Teknik Dalam Layanan Bimbingan Dan Konseling". Anterior Jurnal, 14 (2), 154 - 161.

White, Suzanne Degges, Nancy L. Davis. 2012. Integrating the Expressive Arts Into Counseling Practice Theory-Based Interventions. USA: Richie Herink and Paul Richard Herink.

Wibowo. Mungin Eddy. 2005. Konseling Kelompok Perkembangan. Semarang: Unnes Press. 